\title{
Cloud Computing in Sub-Saharan Africa
}

\section{By: Nir Kshetri}

Kshetri, Nir (2013). "Cloud Computing in Sub-Saharan Africa ", IEEE IT Professional, 15(6), November/December, 64-67.

Made available courtesy of IEEE Computer Society: http://dx.doi.org/10.1109/MITP.2013.92

(C) 2013 IEEE. Personal use of this material is permitted. Permission from IEEE must be obtained for all other uses, in any current or future media, including reprinting/republishing this material for advertising or promotional purposes, creating new collective works, for resale or redistribution to servers or lists, or reuse of any copyrighted component of this work in other works.

\section{***This version of the document is not the version of record. Figures and/or pictures may be missing from this format of the document. $* * *$}

\section{Abstract:}

Cloud-related innovations and services are becoming fundamental sources of economic and societal change in Sub-Saharan African economies, which are embracing cloud computing. This analysis of the cloud market examines both driving and constraining factors in these economies.

Keywords: cloud applications | sub-Saharan Africa | cloud computing | information technology | emerging markets

\section{Article:}

Cloud-related innovations and services are becoming fundamental sources of economic and societal change in Sub-Saharan African economies, which are embracing cloud computing. This analysis of the cloud market examines both driving and constraining factors in these economies.

\section{The Current Market}

Creative cloud-based apps have been developed that are unique to Sub-Saharan Africa, where cloud diffusion is appearing in a variety of areas.

Research and Development

The Computational Intelligence Research Group at University of Pretoria uses the cloud for medical research — in particular, to help develop drugs for treating serious illnesses specific to Sub-Saharan Africa. Also, the Consortium for Advanced Research Training in Africa has worked with Google to develop a virtual research platform, letting nine university partners, four research institutes, and eight partners in North America, Europe, and Australia collaborate on research, 
manage application processes, submit online assignments, attend webinars, and participate in discussion forums. ${ }^{1}$

\section{Education}

The Higher Education Alliance for Leadership through Health, a consortium of seven universities (in Kenya, Ethiopia, the Democratic Republic of Congo, Tanzania, and Uganda), works with industry experts to extend education through virtual labs that students access remotely.

South Africa's Center for Higher Education Transformation lets African universities access and manipulate its performance data stored on a Google platform. ${ }^{1}$ Also, Google has provided its cloud-based Apps for Education to universities in Rwanda, Kenya, and Mauritius.

Microsoft donated 250,000 laptops to teachers in Ethiopia, which run on the Azure cloud platform and let teachers download curriculum; maintain, view, and track academic records; and transfer student data securely (www.eastafricaforum.net).

\section{Healthcare}

In South Africa, the Mothers-2-Mothers (M2M) program combines the cloud with database technology and mobile services to fight HIV/AIDS transmission from mother to children. M2M digitizes patient records and shares them with counselors across its networks of over 700 sites in Africa. The records contain information on treatment plans and advanced reporting tools, which allow quick response. As of 2011, M2M had served more than 1.5 million women in nine SubSaharan African countries.

In Nigeria and Ghana, a cloud-based app is used to identify fake prescription drugs. When buying a drug, a customer can find a 12-digit code by scratching a sticker on the package and can then send a text message to a number. The code is matched with that registered by the pharmaceutical company in HP's cloud database. The customer receives a response back that tells whether the drug is counterfeit.

\section{Agricultural Productivity}

Green Dreams' iCow helps farmers track and manage cows' fertility cycle. It informs them about important days of cow gestation period, collects and stores milk and breeding records, and finds the nearest veterinarian and other service providers. A simple system involving Google Docs is also used. If Green Dreams and the vet can't answer a question, the system uploads the question to the iCow system and vets send messages among themselves to come up with the best answer, which is then forward to the farmer. As of 2012, 42,000 farmers in 42 counties were using iCow, which increased milk production by two to three liters per cow per day. ${ }^{2}$

E-business and E-commerce 
Cheki runs a cloud-based used-car classified business in numerous countries, including Kenya, Nigeria, Malawi, and Ghana. As of 2012, it served one million people, and its website had approximately one billion page views per month.

In addition, Nigeria’s largest jobs and careers website, Jobberman, runs on Amazon Web Services (AWS). South Africa's luxury goods company, 36Boutiques, has also deployed AWS.

\section{Business Process and IT Outsourcing}

South Africa's call center agents and software developers have moved out of dedicated facilities and are embracing cloud-based systems, boosting productivity by 20 percent. ${ }^{3}$ Because they don't need to own and maintain equipment and can log in from anywhere using IP lines, they've lowered their capital investments. ${ }^{3}$

\section{Banking and Finance}

In South Africa, Nedbank has automated business processes through the cloud, and MTN offers SaaS applications for microfinance institutions.

Also, in 2011, Kenya’s Safaricom launched Safaricom Cloud and started hosting Mpesa mobile money service locally. ${ }^{4}$ Furthermore, in early 2013, the Commercial Bank of Africa signed a cloud infrastructure deal with HP to increase its storage capacity by 50 Terabytes.

\section{Environmental Monitoring and Protection}

The United Nations Educational, Scientific, and Cultural Organization (UNESCO) and HP's "brain gain” initiatives entail cloud use to connect students with emigrated researchers. Burkina Faso's University of Ouagadougou has launched projects modeling the movement of pollutants in the Sourou River drainage basin. By 2009, successful pilot projects were carried out in Ghana, Nigeria, Senegal, and Zimbabwe. By 2011, 20 educational institutions in 16 countries benefitted from the project (see http://tinyurl.com/lojktjc).

\section{Modern versus Traditional Sectors}

Table 1 compares cloud deployment in traditional versus modern sectors. The case of Nedbank, which uses services provided by IBM, AWS, and others to cope with high demands, ${ }^{5}$ highlights the growing need for sophisticated applications. Nedbank teamed up with South Africa's Entersect Technologies to develop a secure system based on digital certificates and push notifications. Users approve or deny transactions on phones by entering PINs.

However, financial institutions such as Nedbank might face fluctuations in demand. For example, the end of the month is a high transaction period, because that's when employees are paid. Likewise, the end of the year and holiday shopping seasons face high demands. The system scales up during high transaction periods and scales down in slower periods. ${ }^{5}$ Compared to the more traditional iCow application, Nedbank's application is more costly. For example, digital certificates must be installed on the phone to authenticate transactions. 
Table 1. Cloud deployment in traditional and modern sectors in Sub-Saharan African economies: Green Dreams’ iCow versus Nedbank’s e-banking.

\begin{tabular}{|l|l|l|}
\hline & $\begin{array}{l}\text { Traditional sector (iCow } \\
\text { app) }\end{array}$ & Modern sector (Nedbank's e-banking) \\
\hline User device & Low-priced cell phones & PC or smartphones \\
\hline Method for serving users & Text messages & Internet, text messages \\
\hline $\begin{array}{l}\text { Roles of local cloud } \\
\text { providers }\end{array}$ & $\begin{array}{l}\text { Green Dreams envisioned } \\
\text { and developed the system }\end{array}$ & $\begin{array}{l}\text { The digital certificates placed on the phone and push } \\
\text { notifications were developed by South Africa's Entersect } \\
\text { Technologies }\end{array}$ \\
\hline $\begin{array}{l}\text { Roles of global cloud } \\
\text { providers }\end{array}$ & $\begin{array}{l}\text { It makes limited use of } \\
\text { Google Docs }\end{array}$ & $\begin{array}{l}\text { IBM Cognos platform is used for budgeting and } \\
\text { forecasting. The system exploits Amazon Web Services } \\
\text { to handle massive amounts of mobile phone calls } \\
\text { connecting to its infrastructure. }\end{array}$ \\
\hline Bandwidth requirement & Low & High \\
\hline Importance of security & Low & High \\
\hline
\end{tabular}

\section{Key Driving Factors}

The growth of Sub-Saharan African economies' cloud industry and market is driven by a number of factors, which include local entrepreneurial activities, Western multinationals' entry into the region's cloud sector, improving international bandwidth, international agencies' roles and philanthropic and charitable causes.

\section{Local Entrepreneurial Activities}

Local entrepreneurial activities have helped cloud development. Innovation centers, such as Kenya's iHub, have brought together developers and entrepreneurs. South Africa's Integr8 and MTN, and Zimbabwe's Twenty Third Century Systems, have launched cloud offerings in SubSaharan Africa. MTN MyOffice supports accounting, human resource, customer relationship management, email and videoconferencing, storage and back-up for SMEs in manufacturing, hospitality, microfinance, and advertising.

In 2011, Safaricom launched the Safaricom Cloud, hosting platforms for government agencies and corporations and other offerings. By 2011, it had invested US\$150 million and announced plans to invest another US\$200 million. ${ }^{4}$ Safaricom teamed up with Cisco (storage), EMC (security), and Seven Seas Technology (overseeing and training).

\section{Western Multinationals}

In addition to its Johannesburg data center, IBM built its 41st global innovation center in Kenya in 2013. Other global providers, such as HP and VMware, have a significant presence in SubSaharan Africa. Amazon's customer service center in South Africa opened in 2011 and employs 1,400 people, and in 2012, it launched the AWS Developer Support office in Cape Town.

Specialized providers have also entered Sub-Saharan Africa. In 2012, Switzerland-based Sofgen launched the core banking platform, Temenos T24. It targets banks, microfinance institutions, and savings and credit cooperatives and has built-in fraud detection capabilities. T24's clients include Kenya's Fountain Credit Services and Uganda’s Tropical Bank. ${ }^{6}$ 
Improving Bandwidth

Sub-Saharan Africa's bandwidth has increased dramatically. In 2012, Kenya was connected to SEACOM, The East African Marine System (TEAMS), and East African Submarine Cable System (EASSy) cables, and its bandwidth increased from 20 Gbytes per second to 53 GBps from 2010 to 2011. ${ }^{7}$ In Nigeria, Glo-1 launched in 2009, and other cables in 2010 and 2012 broke Nitel's SAT-3/WASC monopoly. International bandwidth cost fell by 90 percent from 2009 to $2013 .^{8}$

International Agencies

UNESCO and other international agencies’ roles deserve mention. In 2006, the World Bank (WB) and the African Development Bank financed a US\$280 million cable project serving 23 countries. In 2007, the International Finance Corporation invested US\$32.5 million in EASSy, connecting 21 countries. ${ }^{9}$ Likewise, Sierra Leone received US\$31 million to connect to ACE cable through the WB-funded West Africa Regional Communications Infrastructure Program. ${ }^{10}$ The WB also provided bandwidth subsidies to many universities.11

\section{Major Constraints}

There are also major constraints facing the cloud industry and market in Sub-Saharan African economies, which are related to the lack of infrastructure and bandwidth, unaffordable prices, narrow local cloud offerings, and unfavorable regulatory/human development issues.

Insufficient Infrastructure and Bandwidth

In Sub-Saharan Africa, 53 percent of urban populations and 8 percent rural populations have electricity (compared to 99 and 88 percent in North Africa, respectively). A significant proportion of users access Internet resources over limited bandwidths. For example, Sierra Leone's six million people had 155 MBps available in 2011. ${ }^{12}$ In 2011, Africa's international bandwidth was 801 GBps. ${ }^{7}$ However, North Africa (with a population of 200 million) had 433 GBps, whereas Sub-Saharan Africa (population 900 million) had 368 GBps. In 2011, Sierra Leone, the Central African Republic, Chad, the Democratic Republic of Congo, Eritrea, Guinea, Liberia, São Tomé, Príncipe, and Seychelles had no fiber-optic links and users relied on satellites. Moreover, the unavailability of landlines makes it difficult to disperse bandwidth. ${ }^{12}$

\section{High Prices}

Bandwidth, electricity, and other infrastructures are costly. Electricity in Kenya costs $\$ 0.20 / \mathrm{KWH}$, which is 50 percent higher than in the US. Excluding cooling and management, running a Kenyan server costs over US\$1,800 per year. According to the WB, bandwidth costs in Sierra Leone are 10 times higher than those in east Africa and 25 times higher than those in the US. The 2 MBps VSAT connections of embassies, banks, and mining companies cost \$8,000 per month plus installation. $512 \mathrm{KBps}$ connections, provided by ISPs through wireless networks, cost \$570 per month (plus a modem charge of \$445). Mobile-phone companies’ distribution of 
satellite bandwidths packaged in USB sticks, which are extremely slow and unusable at busy times, cost $\$ 70 /$ month. $^{12}$

Narrow Local Offerings

Transferring data from foreign servers results in a latency of hundreds of milliseconds. Moreover, foreign companies require users to pay with credit cards, which only 3 percent of the Sub-Saharan African population has. ${ }^{13}$ Although local firms are leveraging competencies in some segments, they lack capabilities to serve most sectors.

Regulatory and Human Resources

According to the Business Software Alliance, South Africa ranked 20th out of 24 economies analyzed in 2013 in cloud-related regulations. Other Sub-Saharan African economies weren’t ranked in the study, but their rank would be even farther behind. Sub-Saharan Africa economies thus must strengthen regulations and train human resources.

Challenges such as low quality, the high cost of last-mile connections, the remoteness of many areas, and the unavailability of high speed Internet pose opportunities and challenges to cloud providers. The experiences of iCow and M2M indicate that less bandwidth-intensive interfaces and applications are appropriate for most Sub-Saharan African populations, which use the cloud for only a few activities. It would thus be unreasonable to expect that the cloud would allow SubSaharan Africa to catch up with the industrialized countries in one big leap. However, as the factors I've mentioned improve, cloud computing holds promise for bridging the digital divide.

\section{References}

1. C. Frittelli, “African Universities: Ready for the Cloud?” The Chronicle of Higher Education, 21 May 2012; http://chronicle.com/blogs/worldwise/african-universities-ready-forthecloud/29594.

2. "Cows in the Cloud: Kenyans are Registering their Cows, and Increasing their Milk Yields, on their Mobile Phones,” ILRI News, 18 Dec. 2012;

www.ilri.org/ilrinews/index.php/archives/10173.

3. R. Firth, “Use the Cloud to Work from Home,” ITWeb, 13 Aug. 2009.

4. R. Wanjiku, “Safaricom Offers Locally Hosted Cloud Service,” TechAdvisor, 1 Nov. 2011; http://tinyurl.com/ko5gfq6.

5. “Amazon Web Services: Cloud Computing Pioneer,” Technolog y Banker, 2 Jan. 2013; http://tinyurl.com/kcyf5tu.

6. J. Ratemo, “Sofgen Implements New Banking System at Fountain Credit Services,” Business Daily, 4 Nov. 2012; http://tinyurl.com/jw9rzw7. 
7. “Africa’s International Bandwidth Approaches 1 Tbps Mark,” Africa Bandwidth Maps, 4 Apr. 2012; www.africabandwidthmaps.com/?p=2787.

8. P. Budde, “Africa's Largest Telecom Market with More than 110 Million Subscribers,” blog, 26 Apr. 2013; www.buddeblog.com.au/frompaulsdesk/africas-largest-telecom-market-withmorethan-110-million-subscribers.

9. R. Muller, “US 32.7 Million Investment for EASSy,” My Broadband, 14 Aug. 2007; http://mybroadband.co.za/news/telecoms/966-us-32-7-million-investment-for-eassy.html.

10. S. Sesay, "The State of Internet Connectivity in Sierra Leone: Fibre Optic Cable and Electricity,” mysierraleoneonline.com, 7 July 2013;

http://mysierraleoneonline.com/sl_portal/site/news/detail/1481.

11. R. Wanjiku, "East Africa Universities Take Advantage of Google Cloud," Computer World, 12 June 2009; http://news.idg.no/cw/art.cfm?id=D3ED873F-1A64-6A71-CE3B759E5A305061.

12. "www.africa.slow: The Last Continent without Fast, Easy and Cheap Internet Access," The Economist, 27 Apr. 2011; www.economist.com/node/21526937.

13. “Continent of Dreams: Across Africa, Banks are Expanding. Their Returns Aren’t,” The Economist, 2 Mar. 2013; http://tinyurl.com/c6nvs6t.

Nir Kshetri is a professor at the University of North Carolina-Greensboro and a research fellow at Research Institute for Economics \& Business Administration at Kobe University. Contact him atnbkshetr@uncg.edu. 